\title{
THE EFFECT OF DEMOGRAPHIC STRUCTURE ON CARBON DIOXIDE (CO2) EMISSIONS: TOP EMITTERS CASE STUDY
}

Bela Nurrahmawati ${ }^{1}$

\section{Deni Kusumawardani²}

\author{
${ }^{1,2}$ Department of Economics, Faculty of Economics and Business, Universitas Airlangga
}

\begin{abstract}
This study aims to analyze how the demographic structure affects carbon dioxide $\left(\mathrm{CO}_{2}\right)$ emissions in Top Emitters, namely China, the United States, the European Union (EU-28), India, Indonesia, Russia, Brazil, Japan, Canada, and Mexico. This study uses panel data from ten countries stated in Top Emitters for the period 2000-2014 sourced from the World Resource Institute, World Bank and UNESCO Institute for Statistics. This study uses the Panel Data Regression method with the best model chosen is the Random Effect Model (REM) and four demographic structure variables, namely the dependency ratio, sex ratio, higher education ratio, industrial employment ratio. The results of this study indicate that the dependency ratio, sex ratio, higher education ratio, industrial employment ratio have a significant effect on carbon dioxide $\left(\mathrm{CO}_{2}\right)$ emissions in Top Emitters. The results of this study are expected to provide policies that can be implemented by the government.
\end{abstract}

Keywords: Demographic Structure, Top Emitters, Panel Data Regression Method

$J E L: 125,015, Q 5$

\section{ABSTRAK}

Penelitian ini bertujuan untuk menganalisis bagaimana pengaruh struktur demografi terhadap emisi karbon dioksida $\left(\mathrm{CO}_{2}\right)$ di Top Emitters yakni Cina, Amerika Serikat, Uni Eropa (UE-28), India, Indonesia, Rusia, Brasil, Jepang, Kanada, dan Meksiko. Penelitian ini menggunakan data panel sepuluh negara yang dinyatakan dalam Top Emitters selama periode 2000-2014 yang bersumber dari World Resource Institute, World Bank dan UNESCO Institute for Statistic. Studi ini menggunakan metode Regresi Data Panel dengan model terbaik yang terpilih adalah Random Effect Model (REM) dan empat variabel struktur demografi yaitu dependency ratio, sex ratio, higher education ratio, industrial employment ratio. $\mathrm{Ha}$ sil penelitian ini menunjukkan bahwa dependency ratio, sex ratio, higher education ratio, industrial employment ratio berpengaruh signifikan terhadap emisi karbon dioksida $\left(\mathrm{CO}_{2}\right)$ di Top Emitters. Hasil penelitian ini diharapkan dapat memberikan kebijakan yang dapat diimpilementasikan oleh pemerintah.

Kata Kunci: Struktur Demografi, Top Emitters, Metode Regresi Data Panel

JEL : 125, 015, Q5

JIET (Jurnal Ilmu Ekonomi Terapan) p-ISSN: 2541-1470; e-ISSN: 2528-1879

DOI: $10.20473 /$ jiet.v6i1.26397

Open access under a Creative Commons Attribution-ShareAlike 4.0 International

(CC BY-SA) 


\section{Pendahuluan}

Pemanasan global telah menjadi isu lingkungan yang dihadapi masyarakat di seluruh dunia saat ini. World Meteorological Organization-WMO (2018) melaporkan bahwa kenaikan emisi GRK di atmosfer saat ini telah mencapai $146 \%$ lebih tinggi dibandingkan pada saat pra-industri. World Resource Institute-WRI (2014) melaporkan bahwa terdapat sepuluh negara yang menyumbang emisi $\mathrm{CO}_{2}$ tertinggi. Negara tersebut dikelompokkan ke dalam kategori Top Emitters yang meliputi Cina, Amerika Serikat, Uni Eropa, India, Indonesia, Rusia, Brasil, Jepang, Kanada, dan Meksiko. Diantara negara-negara dalam Uni Eropa (UE-28), Jerman merupakan negara yang memiliki emisi tertinggi sebesar 816,64 $\mathrm{MtCO}_{2}$. Top Emitters berkontribusi $75 \%$ terhadap total emisi global yang berasal dari total including Land Use Change and Forestry (LUCF) dan lainnya berasal dari total excluding Land Use Change and Forestry (LUCF).

Konsentrasi emisi $\mathrm{CO}_{2}$ di atmosfer berkembang pesat sebagai akibat dari beragamnya aktivitas manusia yang tidak berkelanjutan dan rendahnya tingkat kepedulian terhadap lingkungan (Salam \& Noguchi, 2005). Adapun sumber emisi $\mathrm{CO}_{2}$ sebagian besar diakibatkan oleh aktivitas manusia atau sering disebut dengan "anthropogenic emission", yaitu bersumber dari pembakaran bahan bakar fosil yang mencapai $80 \%$ sedangkan sisanya $20 \%$ dari kegiatan lain (Bongaarts, 1992; Schlesinger, 2005).

Dietz \& Rosa (1997) menyatakan bahwa peningkatan emisi $\mathrm{CO}_{2}$ yang relatif cepat dapat disebabkan oleh beberapa faktor antropogenik yaitu (1) penduduk, (2) pendapatan, (3) teknologi, (4) politik dan ekonomi. Dari beberapa faktor tersebut, penduduk, pendapatan dan teknologi diyakini sebagai faktor pendorong meningkatnya emisi $\mathrm{CO}_{2}$. Keterkaitan ketiga faktor tersebut kemudian ditransformasikan ke dalambentuk Model IPAT (Impact Population Affluence Technology). Model IPAT dapat digunakan untuk melihat pengaruhnya terhadap GRK dan semua perubahan lingkungan antropogenik.

Beberapa studi tentang pengaruh penduduk terhadap lingkungan lebih membahas mengenai jumlah penduduk, seperti Dietz \& Rosa (1997); Shi (2003); York et al., (2003). Sementara studi yang lain lebih mengembangkan pada jumlah penduduk dengan aspek demografi. Cole \& Neumayer (2004) memasukkan struktur umur (age structure) seperti penduduk berusia di bawah 14 tahun dan penduduk berusia 15-64 tahun. Sedangkan beberapa studi terbaru juga mulai mengembangkan aspek demografi melalui beberapa indikator. Li \& Zhou (2019) di China menggunakan data panel tahun 1996-2015 memasukkan rasio ketergantungan (dependency ratio), rasio jenis kelamin (sex ratio), rasio tenaga kerja industri (industrial employment ratio), rasio pendidikan tinggi (higher education ratio). Uddin (2014) di Bangladesh menggunakan data time series tahun 1974-2010 memasukkan pendidikan (education). Hassan \& Salim (2015) di 25 negara OECD menggunakan data panel tahun 1980-2009 memasukkan penduduk usia tua (ageing). Guo et al. (2016) di China menggunakan data panel tahun 2000-2013 memasukkan penduduk usia muda (children), penduduk usia tua (elderly), pendidikan tinggi (collage). Li \& Zhou (2019) di China menggunakan data panel tahun 2005-2016 memasukkan rasio penduduk laki-laki dan perempuan (gender).

Secara umum, pengaruh dari beberapa studi-studi tersebut terdapat kesimpulan hasil yang sama untuk indikator demografi seperti variabel sex ratio dan gender (Shijie Li \& Zhou, 2019; Shiran Li et al., 2019), higher education ratio, education (Shijie Li \& Zhou, 2019; Uddin, 2014) yang berpengaruh positif terhadap polusi udara. Namun, terdapat perbedaan hasil untuk variabel collage (Guo et al., 2016) yang berpengaruh negatif terhadap polusi udara, sehingga dapat diperoleh kesimpulan bahwa pengaruh dari aspek demografi terhadap emisi $\mathrm{CO}_{2}$ bervariasi diberbagai studi-studi yang telah dilakukan dan untuk negara-negara yang berbeda. 33 
Penelitian ini bertujuan untuk melihat pengaruh struktur demografi terhadap emisi $\mathrm{CO}_{2}$ yang mengacu pada penelitian Shijie Li \& Zhou (2019) di China. Subjek penelitian ini menggunakan 10 negara yang dikategorikan ke dalam Top Emitters dan menggunakan data panel tahun 2000-2014. Penelitian mengenai pengaruh struktur demografi terhadap emisi $\mathrm{CO}_{2}$ menarik untuk diteliti kembali dengan asumsi bahwa terdapat hasil yang bervariasi untuk beberapa studi-studi yang telah dilakukan.

\section{Telaah Literatur}

Karbon dioksida $\left(\mathrm{CO}_{2}\right)$ merupakan salah satu senyawa terpenting di atmosfer. $\mathrm{CO}_{2}$ adalah total karbon yang dihasilkan dari keseluruhan antropogenik yang dapat merusak lingkungan serta menyebabkan ketidakseimbangan di atmosfer (Azad et al., 2006). Karbon dioksida dapat dihasilkan dari pembakaran bahan bakar fosil melalui penggunaan sektor energi, industri manufaktur dan konstruksi, transportasi. Selain itu, $\mathrm{CO}_{2}$ merupakan gas tidak berwarna yang dihasilkan dari semua makhluk hidup (manusia, tumbuhan, hewan) melalui proses respirasi dan digunakan oleh tumbuhan dalam fotosintesis (Islam et al., 2017). Schelling (1992) menjelaskan bahwa karbon dioksida dapat menahan inframerah yang ada pada sinar matahari, sehingga ketika inframerah yang tertahan oleh karbon dioksida yang membawa radiasi panas tidak dapat dipantulkan kembali oleh atmosfer bumi.Kemudian, radiasi panas tersebut terperangkap di bumi yang pada akhinya menyebabkan global warming.

Beberapa teori menyatakan mengenai adanya pengaruh struktur demografi terhadap emisi $\mathrm{CO}_{2}$. Beberapa penelitian atau studi empiris terdahulu seperti penelitian yang dilakukan oleh Shijie Li \& Zhou (2019) dimana tujuan dari penelitiannya untuk menyelidiki dampak struktur demografi terhadap emisi $\mathrm{CO}_{2}$ di China pada tingkat nasional dan regional periode 1996-2015. Dengan menggunakan empat variabel struktur demografi yaitu depedency ratio, sex ratio, higher education ratio, industrial employment ratio. Penelitian ini menggunakan metode Panel Cointegration Modelling yang digunakan untuk menguji hubungan jangka panjang antara emisi $\mathrm{CO}_{2}$ dan empat variabel struktur demografi. Hasilnya menunjukkan bahwa hubungan jangka panjang antara emisi $\mathrm{CO}_{2}$ dan struktur demografis ada di tingkat nasional dan regional. Dependency ratio ditemukan memberikan hubungan negatif pada emisi $\mathrm{CO}_{2}$ dan hubungan positif sex ratio, higher education, industrial employmet ratio pada emisi.

Penelitian Uddin (2014) memiliki tujuan untuk menguji hubungan antara pendidikan, emisi $\mathrm{CO}_{2}$ dan pertumbuhan ekonomi di Bangladesh periode 1974-2010. Teknik Vector Error Correction Mechanism (VECM) diterapkan untuk membangun hubungan jangka panjang dan jangka pendek antara variabel dalam model. Hasil temuannya menunjukkan hubungan positif yang kuat antara emisi $\mathrm{CO}_{2}$ dan pendidikan. Hasil penelitian ini akan membantu untuk memahami dampak pertumbuhan ekonomi terhadap penurunan kualitas lingkungan dan mengelola emisi $\mathrm{CO}_{2}$ dengan menciptakan kesadaran melalui pendidikan.

Terdapat teori yang menyatakan bahwa penduduk tua (ageing) dapat mengurangi emisi $\mathrm{CO}_{2}$. Pernyataan ini didukung oleh penelitian Hassan dan Salim (2015), dimana tujuan dari penelitian ini menunjukkan adanya pengaruh struktur usia terhadap emisi $\mathrm{CO}_{2}$ di 25 negara OECD periode 1980-2010. Hasil empiris penelitian tersebut menunjukkan bahwa penduduk tua (ageing) mengurangi emisi $\mathrm{CO}_{2}$ dalam jangka panjang. Dalam vektor kointegrasi menunjukkan bahwa dalam jangka panjang, peningkatan 1 persen dalam populasi penduduk berusia lanjut akan mengurangi emisi $\mathrm{CO}_{2}$ per kapita sebesar 1,55 persen. Guo et al. (2016) tujuan penelitian ini menganalisis perubahan struktur penduduk pada emisi $\mathrm{CO}_{2}$ dengan menggunakan periode 2003-2012. Menggunakan model Logarithmic Mean Divisia Index (LMDI). Hasil 
penelitian ini menunjukkan elderly, children, college berpengaruh negatif terhadap emisi $\mathrm{CO}_{2}$.

Perubahan dalam struktur penduduk, struktur pendidikan, dan struktur pekerjaan penduduk dapat mengurangi pertumbuhan emisi $\mathrm{CO}_{2}$. Hal ini didukung oleh penelitian Shiran Li et al. (2019), penelitian ini bertujuan menunjukkan adanya pengaruh rasio penduduk laki-laki dan perempuan (gender) terhadap emisi $\mathrm{CO}_{2}$ di China periode 2005-2016. Menggunakan metode Bayesian Posterior Probability Model Structure Selection Method. Penelitian menunjukkan bahwa rasio penduduk laki-laki dan perempuan (gender) berpengaruh positif dan signifikan terhadap emisi $\mathrm{CO}_{2}$. Berdasarkan uraian latar belakang dan teori-teori di atas, maka hipotesis dalam penelitian ini adalah dependency ratio, sex ratio, higher education ratio, industrial employment ratio berpengaruh signifikan terhadap emisi $\mathrm{CO}_{2}$ di Top Emitters.

\section{Metode Penelitian}

Penelitian ini menggunakan pendekatan kuantitatif dengan menggunakan Model Regresi Data Panel. Dalam mengestimasi model regresi data panel ini dilakukan melalui tiga pendekatan, yaitu Pooled Least Square (PLS), Fixed Effect Model (FEM), dan Random Effect Model (REM). Pendekatan kuantitatif ini dilakukan untuk mengestimasi kontribusi variabel dependency ratio, sex ratio, higher education ratio dan industrial employment ratio terhadap emisi $\mathrm{CO}_{2}$ di Top Emitters. Data yang digunakan merupakan data panel dari beberapa negara di dunia, sedangkan pengujian dan analisis menggunakan "STATA 13". Model analisa pada penelitian ini mengacu pada penelitian Shijie Li \& Zhou (2019) sebagai berikut:

$$
L n C E_{i t}=a+b \ln D R_{i t}+c \ln S R_{i t}+d \ln H E R_{i t}+e \ln I E R_{i t}+\varepsilon_{i t}
$$

Keterangan:

$$
\begin{array}{ll}
\mathrm{CE} & : \text { Emisi Karbon Dioksida }\left(\mathrm{CO}_{2}\right) \\
\mathrm{DR} & : \text { Dependency Ratio } \\
\mathrm{SR} & : \text { Sex Ratio } \\
\mathrm{HER} & : \text { Higher Education Ratio } \\
\text { IER } & : \text { Industrial Employment Ratio } \\
\alpha, \mathrm{b}, \mathrm{c}, \mathrm{d}: \text { Koefisien regresi } \\
i \quad: \text { Unit Cross Section, yaitu negara emisi tertinggi (Top Emitters) } \\
t \quad: \text { Unit Time Series, yaitu tahun 2000-2014 } \\
\varepsilon \quad \text { : error term }
\end{array}
$$

\section{Jenis dan Sumber Data}

Penelitian ini menggunakan data sekunder, meliputi data kuantitatif dan berbentuk panel. Jenis dan sumber data dapat dilihat pada Tabel 1.

Tabel 1: Jenis dan Sumber Data

\begin{tabular}{clcl}
\hline No & \multicolumn{1}{c}{ Nama Variabel } & Jenis Data & \multicolumn{1}{c}{ Sumber Data } \\
\hline 1 & Emisi $\mathrm{CO}_{2}$ (CE) & Sekunder & World Resource Institute \\
\hline 2 & Dependency Ratio (DR) & Sekunder & World Bank \\
\hline 3 & Sex Ratio (SR) & Sekunder & World Bank \\
\hline 4 & $\begin{array}{l}\text { Higher Education Ratio } \\
\text { (HER) }\end{array}$ & Sekunder & Unesco Institute for Statistic \\
\hline
\end{tabular}




\begin{tabular}{|c|c|c|c|}
\hline No & Nama Variabel & Jenis Data & Sumber Data \\
\hline 5 & $\begin{array}{l}\text { Industrial Employment } \\
\text { Ratio (IER) }\end{array}$ & Sekunder & World Bank \\
\hline
\end{tabular}

\section{Pemilihan Model Panel}

\section{Uji Chow Test atau Uji F Statistic}

Uji chow test dapat digunakan untuk memilih model terbaik antara PLS dan FEM. Dalam mengestimasi data panel penentuan pengujian ini menggunakan rumus:

$$
F=\frac{\left(R^{2} u r-R^{2}\right) /(m)}{\left(1-R^{2} u r\right) /(n-k)}
$$

Keterangan:

$R^{2} r \quad: R^{2}$ model Pooled Least Square (PLS)

$R^{2} u r \quad: R^{2}$ model Fixed Effect Model (FEM)

$\mathrm{m} \quad$ : jumlah restricted variabel

n : jumlah sample

k : jumlah variabel bebas

Dengan Hipotesis Uji Chow Test adalah sebagai berikut:

$\mathrm{H}_{0} \quad$ : Model Pooled Least Square (PLS)

$\mathrm{H}_{1} \quad$ : Model Fixed Effect Model (FEM)

Dalam rumus di atas, jika diperoleh nilai $F_{\text {hitung }}>F_{\text {tabel }}$ maka nilai probabilitas $F<\alpha$ dengan tingkat signifikansi $\left(0.01,0.05\right.$ dan 0.1) menunjukkan $H_{0}$ ditolak atau tidak menerima teknik $\mathrm{PLS}$. Kesimpulan dari hasil ini menunjukkan bahwa $\mathrm{H}_{1}$ tidak ditolak atau menerima teknik Fixed Effect Model (FEM).

\section{Uji Hausman}

$\mathrm{H}_{0} \quad$ : Model Random Effect Model (REM)

$\mathrm{H}_{1} \quad$ : Model Fixed Effect Model (FEM)

Apabila dalam uji hausman nilai probabilitas $<\alpha$ maka menunjukkan $\mathrm{H}_{0}$ ditolak atau tidak menerima teknik REM. Kesimpulan dari hasil ini menunjukkan bahwa $\mathrm{H}_{1}$ tidak ditolak atau menerima teknik Fixed Effect Model (FEM). Namun sebaliknya, apabila uji hausman nilai probabilitas > a maka $\mathrm{H}_{1}$ tidak ditolak atau menerima teknik REM.

\section{Uji LM Test (Breusch Pagan Langrangian Multiplier Test)}

Uji LM Test dapat dugunakan untuk memilih antara PLS dan REM. Dengan membandingkan nilai probabilitas Chi-Square terhadap $\alpha(0.01,0.05$ dan 0.1). Hipotesis untuk menguji LM Test adalah:

$\mathrm{H}_{0} \quad$ : Model Pooled Least Square (PLS)

$\mathrm{H}_{1} \quad$ : Model Random Effect Model (REM)

Apabila dalam uji LM Test nilai probabilitas < $\alpha$ maka menunjukkan $\mathrm{H}_{0}$ ditolak atau tidak menerima teknik PLS. Kesimpulan dari hasil ini menunjukkan bahwa $\mathrm{H}_{1}$ tidak ditolak atau menerima teknik REM. 


\section{Uji Signifikansi Statistik}

Setelah melakukan pengujian di atas, maka langkah selanjutnya yaitu melakukan uji signifikansi statistik pada masing-masing variabel. Pengujian ini dilakukan dengan metodemetode sebagai berikut:

\section{Uji t (Parsial)}

Uji t sering dikenal sebagai uji parsial, pengujian ini digunakan untuk melihat pengaruh signifikansi koefisien masing-masing variabel bebas terhadap variabel terikat. Adapun hipotesis dalam uji t adalah:

$H_{0}: \beta_{1}=0$ (tidak ada pengaruh secara parsial variabel bebas terhadap variabel terikat)

$H_{1}: \beta_{1} \neq 0$ (ada pengaruh secara parsial variabel bebas terhadap variabel terikat)

Secara umum pengujian ini dilakukan dengan melihat hasil regresi t hitung dengan $\mathrm{t}$ tabel. Jika nilai $\mathrm{t}$ hitung $<\mathrm{t}$ tabel maka dapat disimpulkan bahwa $\mathrm{H}_{0}$ tidak ditolak dan $\mathrm{H}_{1}$ diterima. Maka kesimpulannya, dimana variabel bebas tidak berpengaruh terhadap variabel terikat. Sebaliknya jika $\mathrm{t}$ hitung $>\mathrm{t}$ tabel maka $\mathrm{H}_{0}$ ditolak dan $\mathrm{H}_{1}$ diterima yang artinya variabel bebas berpengaruh terhadap variabel terikat.

Selain itu, uji t dapat dilakukan dengan melihat nilai probabilitas ( $p$-value) pada masing-masing variabel. Jika nilai probabilitas $<\alpha(0.01,0.05$ dan 0.1$)$ maka variabel bebas signifikan menjelaskan variabel terikat, karena berada pada daerah penolakan $\mathrm{H}_{0}$. Dimana semakin kecil $\alpha$ maka tingkat kesalahan rendah sehingga hasil yang diperoleh meyakinkan, begitu sebaliknya jika $\alpha$ yang digunakan semakin tinggi sehingga hasil yang diperoleh kurang meyakinkan.

\section{Uji F (Simultan)}

Uji F sering dikenal sebagai uji simultan, pengujian ini digunakan untuk melihat pengaruh variabel bebas terhadap variabel terikat secara bersama-sama. Adapun hipotesis dalam Uji F adalah:

$H_{0}: \beta_{1}=\beta_{2}=\ldots . .=\beta_{n}=0$

$\mathrm{H}_{1}$ : Paling tidak ada satu parameter $\beta \neq 0$

Secara umum pengujian dalam Uji $F$ tidak jauh beda dengan Uji $t$, yaitu sama-sama melihat nilai $\mathrm{F}$ tabel dan probabilitas ( $p$-value). Dalam Uji $\mathrm{F}$ dapat dilakukan dengan melihat hasil regresi $\mathrm{F}$ hitung dengan $\mathrm{F}$ tabel. Jika nilai $\mathrm{F}$ tabel $<\mathrm{F}$ hitung maka dapat disimpulkan bahwa $\mathrm{H}_{0}$ diterima dan $\mathrm{H}_{1}$ ditolak, sehingga secara simultan variabel bebas tidak berpengaruh terhadap variabel terikat. Selain itu pengujian F-statistik dapat dilakukan dengan meihat nilai probabilitasnya (uji $p$-value). Jika nilai probabilitas ( $p$-value) lebih kecil dari tingkat signifikan yaitu $\alpha(0.01,0.05$ dan 0.1$)$ maka hasilnya berada pada daerah penolakan atau $\mathrm{H}_{0}$ ditolak dan $\mathrm{H}_{1}$ diterima, sehingga variabel bebas secara simultan berpengaruh terhadap variabel terikat.

\section{Koefisien Determinasi $\left(\mathbf{R}^{2}\right)$}

Koefisien determinasi (Goodess of Fit) yang dinotasikan dengan $\mathrm{R}^{2}$ merupakan suatu ukuran yang penting dalam sebuah regresi, karena dapat menginformasikan baik tidaknya model regresi yang melalui estimasi. Menurut Gujarati (2010:201) koefisien determinasi $\left(R^{2}\right)$ mengukur proporsi atau persentase total variasi variabel terikat yang dijelaskan oleh model regresi. Nilai $R^{2}$ mencerminkan seberapa besar variasi dari variabel terikat yang dapat dijelas- 
kan oleh variabel bebas, jika nilai $R^{2}=0$ yang artinya variabel terikat tidak dapat diterangkan oleh variabel bebas. Namun, jika $R^{2}=1$ yang artinya variabel terikat secara keseluruhan dapat diterangkan oleh variabel bebas. Dengan demikian, baik buruknya suatu persamaan regresi dapat ditentukan oleh $\mathrm{R}^{2}$ yang memiliki nilai antara 0 dan 1.

\section{Hasil Dan Pembahasan}

\section{Deskriptif Statistik Variabel}

Tabel 2 menunjukkan bahwa variabel Emisi $\mathrm{CO}_{2}$ memiliki rata-rata 2039 sedangkan nilai minimum 402.18 dan nilai maksimum 100016.83 dengan standart deviasi 2130.638. Dependency ratio memiliki rata-rata 49.625 sedangkan nilai minimum 35.5904 dan nilai maksimum 64.7402 dengan standart deviasi 6.95125. Sex Ratio memiliki rata-rata 98.49674 sedangkan nilai minimum 86.48314 dan nilai maksimum 107.7574 dengan standart deviasi 5.471569 . Higher Education Ratio memiliki rata-rata 3.19 sedangkan nilai minimum 20604444 dan nilai maksimum 1.31 dengan standart deviasi 4.07. Industrial Employment Ratio memiliki rata-rata 24.33043 sedangkan nilai minimum 15.911 dan nilai maksimum 33.531 dengan standart deviasi 4.359674. Adapun analisis deskriptif tersebut disajikan dalam bentuk tabel berdasarkan masing-masing variabel.

Tabel 2: Ringkasan Deskriptif Statistik Variabel

\begin{tabular}{lccrrrr}
\hline \multicolumn{1}{c}{ Variabel } & Notasi & Obs & Mean & \multicolumn{1}{c}{ Min } & \multicolumn{1}{c}{ Max } & \multicolumn{1}{c}{ SD } \\
\hline${\text { Emisi } \mathrm{CO}_{2}}_{\text {Dependency Ratio }}$ & $\mathrm{CE}$ & 150 & 2039 & 402.18 & 10016.83 & 2130.638 \\
\hline Sex Ratio & $\mathrm{DR}$ & 150 & 49.62551 & 35.5904 & 64.7402 & 6.95125 \\
\hline Higher Eucation Ratio & $\mathrm{SR}$ & 150 & 98.49674 & 86.48314 & 107.7574 & 5.471569 \\
\hline Industrial Empoyment Ratio & HER & 150 & $3.19 \mathrm{e}+07$ & 2060444 & $1.31 \mathrm{e}+08$ & $4.07 \mathrm{e}+07$ \\
\hline
\end{tabular}

Sumber: Hasil Olahan STATA Versi 13

\section{Analisis Model dan Pembuktian Hipotesis}

\section{Hasil Estimasi Regresi Data Panel}

Tabel 3 merupakan hasil yang diperoleh dari pengolahan data panel menggunakan tiga metode estimasi diantaranya Pooled Least Square (PLS), Fixed Effect Model (FEM), dan Random Effect Model (REM). Adapun tujuan penelitian ini adalah menganalisis pengaruh struktur demografi terhadap emisi $\mathrm{CO}_{2}$ pada tahun 2000-2014. Penelitian ini menggunakan satu variabel dependen yaitu emisi $\mathrm{CO}_{2}$ (LnCE), dan empatvariabel independen yaitu Dependency Ratio (LnDR), Sex Ratio (LnSR), Higher Education Ratio (LnHER), Industrial Employment Ratio (LnIER). 
Tabel 3: Hasil Estimasi Regresi Data Panel Panel (PLS, FEM, REM)

\begin{tabular}{cccc}
\hline Variabel & PLS & FEM & REM \\
\hline C & 20.57858 & -57.91536 & -28.56231 \\
& $(4.7493)$ & $(16.96778)$ & $(13.18994)$ \\
Dependency Ratio (InDR) & -2.814766 & -0.2865312 & -0.5793981 \\
& $(0.3450)^{* * *}$ & $(0.3504)$ & $(0.3124)^{* * *}$ \\
Sex Ratio (InSR) & -1.651738 & 11.42994 & 6.1788863 \\
& $(1.0703)$ & $(3.9847)^{* *}$ & $(3.1518)^{* * *}$ \\
Higher Education Ratio (InHER) & 0.438917 & 0.6282545 & 0.3944071 \\
& $(0.4769)^{* * *}$ & $(0.3028)^{* * *}$ & $(0.1797)^{* * *}$ \\
Industrial Employment Ratio (InIER) & -0.6511936 & 1.076763 & 0.999594 \\
& $(0.2728)^{*}$ & $(0.2164)^{* * *}$ & $(0.2432)^{* * *}$ \\
R-squared ( $\left.{ }^{2}\right)$ & 0.5987 & 0.2565 & 0.3178 \\
Prob (F-stat) & 0.0000 & 0.000 & 0.000 \\
Observasi & 150 & & \\
\hline
\end{tabular}

Sumber : Hasil Olahan STATA Versi 13

Keterangan: LnCE: Emisi $\mathrm{CO}_{2}$ ( ): Standart Error, ${ }^{* * *}$ : Signifikan ( $\left.\alpha=10 \%\right)$

Pemilihan Model Analisis

Tabel 4 menunjukkan uji Chow Test dan uji Hausman Test sesuai dengan hasil keputusan pemilihan metode regresi data panel maka diperoleh kesimpulan $\mathrm{HO}$ ditolak karena prob uji Chow 0.000 yang berarti nilai probabilitas $0.000<0.1$ ( $\alpha 10 \%$ ) sehingga model yang terbaik yaitu FEM. Berdasarkan hasil uji Hausman Test maka diperoleh kesimpulan HO diterima karena prob uji Hausman 0.7471 yang berarti nilai probabilitas $0.7471>0.1$ ( $\alpha 10 \%)$ sehingga model yang terbaik yaitu REM. Selanjutnya, pembahasan dan analisis yang digunakan adalah Random Effect Model (REM).

Tabel 4: Hasil Uji Chow Test dan Uji Hausman Test

\begin{tabular}{|c|c|c|}
\hline PLS atau FEM & \multicolumn{2}{|l|}{ FEM atau REM } \\
\hline H0 : PLS (Pooled Least Square) & \multicolumn{2}{|l|}{ HO : REM (Random Effect Model) } \\
\hline H1 : FEM (Fixed Effect Model) & \multicolumn{2}{|l|}{ H1 : FEM (Fixed Effect Model) } \\
\hline Alpha $(\alpha)=10 \%$ & \multicolumn{2}{|l|}{ Alpha $(\alpha)=10 \%$} \\
\hline Kriteria Pengujian: & \multicolumn{2}{|l|}{ Kriteria Pengujian: } \\
\hline H0 ditolak jika prob uji Chow $<10 \%$ & HO ditolak jika prob uji Hausman & $<10 \%$ \\
\hline H0 diterima jika prob uji Chow > 10\% & HO diterima jika prob uji Hausman & $>10 \%$ \\
\hline Kesimpulan : & \multicolumn{2}{|l|}{ Kesimpulan : } \\
\hline Prob Uji Chow $=0.000$ & \multicolumn{2}{|l|}{ Prob Uji Hausman= 0.7471} \\
\hline $\begin{array}{l}\text { Jadi, HO ditolak sehingga model yang terpilih } \\
\text { adalah Fixed Effect Model (FEM) }\end{array}$ & \multicolumn{2}{|c|}{$\begin{array}{l}\text { Jadi, HO diterima sehingga model yang terpilih } \\
\text { adalah Random Effect Model (REM) }\end{array}$} \\
\hline
\end{tabular}

Sumber: Data diolah 
Persamaan regresi dari pengaruh struktur demografi terhadap emisi $\mathrm{CO}_{2}$ di Top Emitters pada tahun 2000-2014 dapat ditulis sebagai berikut:

$$
\overline{L n C E_{i t}}=-28.6523-0.5794 \operatorname{LnDR}_{i t}+6.1789 \operatorname{LnSR}_{i t}+0.3944 \operatorname{LnHER}_{i t}+0.9996 \operatorname{LnIER}_{i t}
$$

\section{Uji t (Parsial)}

Uji t (parsial) digunakan untuk melihat pengaruh masing-masing variabel independen terhadap variabel dependen. Pada penelitian ini uji t dilakukan dengan cara membandingkan nilai probabilitas dengan tingkat signifikansinya ( $\alpha=0.010 .050 .1$ ).

Tabel 5: Hasil Uji t-statistik REM

\begin{tabular}{lrcc}
\hline \multicolumn{1}{c}{ Variabel } & \multicolumn{1}{c}{ Koefisien } & Prob t-stat & Hubungan \\
\hline Dependency Ratio (LnDR) & -0.5793981 & 0.064 & Negatif $(-)$ \\
\hline Sex Ratio (LnSR) & 6.178863 & 0.050 & Positif $(+)$ \\
\hline Higher Eucation Ratio (LnHER) & 0.3944071 & 0.028 & Positif $(+)$ \\
\hline Industrial Empoyment Ratio (LnIER) & 0.999594 & 0.000 & Positif $(+)$ \\
\hline
\end{tabular}

Sumber: Data diolah

\section{Uji F (Simultan)}

Hasil estimasi menunjukkan nilai probabilitas F-statistik sebesar 0.000 dengan signifikan pada 0.1 ( $\alpha=10 \%$ ). Berdasarkan uji $F$ diperoleh kesimpulan bahwa variabel dependency ratio, sex ratio, higher education ratio, industrial employment ratio secara bersama-sama berpengaruh signifikan terhadap variabel emisi $\mathrm{CO}_{2}$ di Top Emitters tahun 2000-2014.

\section{Koefisien Determinasi $\left(\mathbf{R}^{2}\right)$}

Hasil estimasi menunjukkan nilai $\mathrm{R}^{2}$ sebesar 0.3178 , artinya 0.32 persen emisi $\mathrm{CO}_{2}$ dipengaruhi oleh dependency ratio, sex ratio, higher education ratio, industrial employment ratio, sisanya 0.68 persen dipengaruhi oleh variabel lain yang tidak dimasukkan dalam model. Nilai ini mengindikasikan bahwa model tersebut cukup dalam menjelaskan pengaruh variabel independen terhadap variabel dependen.

\section{Pembuktian Hipotesis}

Berdasarkan hasil regresi pada Tabel 4.2 maka dapat disimpulkan pembuktian hipotesis yaitu variabel dependency ratio, sex ratio, higher education ratio, industrial employment ratio berpengaruh terhadap emisi $\mathrm{CO}_{2}$ di Top Emitters. Hipotesis ini terbukti karena variabel dependency ratio memiliki nilai koefisien negatif dan signifikan terhadap emisi $\mathrm{CO}_{2}$ di Top Emitters tahun 2000-2014. Sedangkan, variabel sex ratio, higher education ratio, industrial employment ratio memiliki nilai koefisien positif dan signifikan terhadap emisi $\mathrm{CO}_{2}$ di Top Emitters tahun 2000-2014.

\section{Pembahasan}

\section{Dependency Ratio dan Emisi $\mathrm{CO}_{2}$}

Hasil studi pada regresi ini menunjukkan bahwa variabel dependency ratio berpengaruh negatif dan signifikan terhadap emisi $\mathrm{CO}_{2}$ di Top Emitters. Pada hasil regresi ini mempunyai nilai koefisien negatif yang menunjukkan bahwa ketika dependency ratio meningkat sebesar 1 persen, maka akan menurunkan emisi $\mathrm{CO}_{2}$ sebesar 0.5794 persen dengan asumsi variabel lain konstan. Secara teori bahwa hubungan dependency ratio dan emisi $\mathrm{CO}_{2}$ berpen- 
garuh negatif, sejalan dengan penelitian Hassan \& Salim (2015) menemukan bahwa penduduk usia tua berpengaruh negatif terhadap emisi $\mathrm{CO}_{2}$, yang menunjukkan bahwa peningkatan 1 persen dari penduduk usia tua akan mengurangi emisi sebesar 1.55 persen ; Shijie Li \& Zhou (2019) menunjukkan bahwa rasio ketergantungan (dependency ratio) berpengaruh negatif terhadap emisi $\mathrm{CO}_{2}$; Guo et al. (2016) menemukan bahwa penduduk usia tua (elderly) dan penduduk usia muda (chlidren) berpengaruh negatif terhadap emisi $\mathrm{CO}_{2}$. Pada penelitian ini, koefisien determinasi sebesar 0.2266 berarti variabel dependency ratio dapat menjelaskan 23 persen perubahan emisi $\mathrm{CO}_{2}$ dengan asumsi variabel lain konstan, sedangkan sisanya 77 persen dijelaskan oleh variabel lain diluar model.

\section{Sex Ratio Terhadap Emisi $\mathrm{CO}_{2}$}

Hasil studi pada regresi ini menunjukkan bahwa variabel sex ratio berpengaruh positif dan signifikan terhadap emisi $\mathrm{CO}_{2}$ di Top Emitters. Pada hasil regresi ini mempunyai nilai koefisien positif yang menunjukkan bahwa ketika sex ratio meningkat 1 persen, maka akan menurunkan emisi $\mathrm{CO}_{2}$ sebesar 6.1789 persen dengan asumsi variabel lain konstan. Secara teori bahwa hubungan sex ratio dan emsi $\mathrm{CO}_{2}$ berpengaruh positif sejalan dengan penelitian Shijie Li \& Zhou (2019) menunjukkan bahwa rasio jenis kelamin (sex ratio) berpengaruh negatif terhadap emisi $\mathrm{CO}_{2}$; Li dkk (2019) menemukan bahwa rasio penduduk laki-laki dan perempuan (gender)berpengaruh negatif terhadap emisi $\mathrm{CO}_{2}$. Dalam penelitian ini, koefisien determinasi sebesar 0.0897 berarti variabel sex ratio dapat menjelaskan 10 persen perubahan emisi $\mathrm{CO}_{2}$ dengan asumsi variabel lain konstan, sedangkan sisanya 90 persen dijelaskan oleh variabel lain di luar model.

\section{Higher Education Ratio dan Emisi $\mathrm{CO}_{2}$}

Hasil studi pada regresi ini menunjukkan bahwa variabel higher eduation ratio berpengaruh positif dan signifikan terhadap emisi $\mathrm{CO}_{2}$ di Top Emitters. Pada hasil regresi ini mempunyai nilai koefisien positif yang menunjukkan bahwa ketika higher education ratio meningkat 1 persen, maka akan menurunkan emisi $\mathrm{CO}_{2}$ sebesar 0.3944 persen dengan asumsi variabel lain konstan. Secara teori bahwa hubungan higher education ratio dan emsi $\mathrm{CO}_{2}$ berpengaruh positif sejalan dengan penelitian Shijie Li \& Zhou (2019) menunjukkan bahwa rasio pendidikan tinggi (higher education ratio)berpengaruh positif terhadap emisi $\mathrm{CO}_{2}$; Uddin (2014) pendidikan (education) berpengaruh positif terhadap emisi $\mathrm{CO}_{2}$, sedangkan Guo et al. (2016) pendidikan tinggi (collage) berpengaruh negatif terhadap emisi $\mathrm{CO}_{2}$. Pada penelitian ini, koefisien determinasi sebesar 0.2779 berarti variabel higher education ratio dapat menjelaskan 28 persen perubahan emisi $\mathrm{CO}_{2}$ dengan asumsi variabel lain konstan, sedangkan sisanya 72 persen dijelaskan oleh variabel lain di luar model.

\section{Industrial Employment Ratio dan Emisi $\mathrm{CO}_{2}$}

Hasil studi pada regresi ini menunjukkan bahwa variabel industrial employment ratio berpengaruh positif dan signifikan terhadap emisi $\mathrm{CO}_{2}$ di Top Emitters. Pada hasil regresi ini mempunyai nilai koefisien positif yang menunjukkan bahwa ketika industrial employment ratio meningkat 1 persen, maka akan menurunkan emisi $\mathrm{CO}_{2}$ sebesar 0.9996 persen dengan asumsi variabel lain konstan. Secara teori bahwa hubungan industrial employment ratio dan emsi $\mathrm{CO}_{2}$ berpengaruh positif sejalan dengan penelitian Shijie Li \& Zhou (2019) menunjukkan bahwa rasio tenaga kerja industri (industrial employment ratio) berpengaruh positif terhadap emisi $\mathrm{CO}_{2}$. Gambar 4.9 menunjukkan sebaran data antara industrial employment ratio dan emisi $\mathrm{CO}_{2}$. Koefisien determinasi sebesar 0.012 yang berarti variabel industrial employment ratio dapat menjelaskan 1 persen perubahan emisi $\mathrm{CO}_{2}$ dengan asumsi variabel lain konstan, 
sedangkan sisanya 99 persen dijelaskan oleh variabel lain di luar model.

\section{Kesimpulan Dan Saran}

Berdasarkan hasil analisa dan pembahasan yang telah diuraikan dalam penelitian ini, maka dapat disimpulkan berdasarkan hasil analisis regresi data panel menunjukkan bahwa secara parsial variabel dependency ratio memiliki nilai koefisien negatif dan berpengaruh signifikan terhadap emisi $\mathrm{CO}_{2}$ di Top Emitters. Sedangkan, variabel sex ratio, higher education ratio, industrial employment ratio memiliki nilai koefisien positif dan berpengaruh signifikan terhadap emisi $\mathrm{CO}_{2}$ di Top Emitters. Setelah melihat hasil analisis dalam penelitian yang telah dilakukan, penulis berusaha memberikan beberapa saran. Pertama, tren dalam peningkatan penduduk usia tua dan kurang tersedianya penduduk usia kerja (produktif) maka diharapkan untuk dapat memperhatikan kebijakan perencanaan keluarga khususnya tingkat kesuburan. Kedua, secara khusus dapat mengoptimalkan kesetaraan antara penduduk laki-laki dan perempuan di daerah yang kurang berkembang. Ketiga, tingkat pendidikan merupakan bagian terpenting dari setiap individu. Jika, dilihat pengaruh pendidikan terhadap lingkungan yang tidak terhindarkan maka diharapkan dapat memberikan kesadaran lingkungan dan pola hidup yang berkelanjutan, gaya hidup yang tidak intensif energi, konsumsi energi secara optimal baik di negara maju dan negara berkembang. Keempat, tenaga kerja di sektor industri memiliki peran penting dalam perkembangan ekonomi. Namun, seiring dengan perkembangan tersebut berdampak pada peningkatan emisi $\mathrm{CO}_{2}$ yang semakin tinggi. Terserapnya tenaga kerja di sektor industri harus diimbangi dengan penggunaan teknologi yang ramah lingkungan agar dapat mengurangi peningkatan emisi $\mathrm{CO}_{2}$. Sementara itu, industrialisasi harus dipercepat dan pembangunan ekonomi harus diberi prioritas utama di daerah yang kurang berkembang.

\section{Daftar Pustaka}

Azad, A. K., Nashreen, S. W., \& Sultana, J. (2006). State of energy consumption and CO2 emission in Bangladesh. Ambio, 35(2), 86-88.

Bongaarts, J. (1992). Population Growth and Global Warming. Population and Development Review, 18(2), 299-319.

Cole, M. A., \& Neumayer, E. (2004). Examining the Impact of Demographic Factors on Air Pollution. Population and Environment, 26(1), 5-21.

Dietz, T., \& Rosa, E. A. (1997). Effects of population and affluence on CO2 emissions. Proceedings of the National Academy of Sciences of the United States of America, 94(1)

Guo, W., Sun, T., \& Dai, H. (2016). Effect of Population Structure Change on Carbon Emission in China. Sustainability, 8(3).

Hassan, K., \& Salim, R. (2015). Population ageing, Income growth and CO2 emission: Empirical evidence from high income oecd countries. Journal of Economic Studies, 42(1), 54-67.

Gujarati, Damodar. 2003. Ekonometrika Dasar : Edisi Keenam. Jakarta: Erlangga.

Islam, R., Ghani, A. B. A., \& Mahyudin, E. (2017). Carbon dioxide emission, energy consumption, economic growth, population, poverty and forest area: Evidence from panel data analysis. International Journal of Energy Economics and Policy, 7(4), 99-106.

Li, Shijie, \& Zhou, C. (2019). What are the impacts of demographic structure on CO(2) emissions? A regional analysis in China via heterogeneous panel estimates. The Science of 
the Total Environment, 650(Pt 2), 2021-2031.

Li, Shiran, Deng, H., \& Zhang, K. (2019). The Impact of Economy on Carbon Emissions: An Empirical Study Based on the Synergistic Effect of Gender Factors. International Journal of Environmental Research and Public Health, 16(19).

Salam, M. A., \& Noguchi, T. (2005). Impact of Human Activities on Carbon Dioxide (CO2) Emissions: A Statistical Analysis. Environmentalist, 25(1), 19-30.

Schelling, T. (1992). Some Economics of Global Warming. American Economic Review, 82(1), 1-14.

Schlesinger, W. H. (2005). The Global Carbon Cycle and Climate Change. In W. Sinnott-Armstrong \& R. B. Howarth (Eds.), Perspectives on Climate Change: Science, Economics, Politics, Ethics (Vol. 5, pp. 31-53).

Shi, A. (2003). The Impact of Population Pressure on Global Carbon Dioxide Emissions, 19751996: Evidence from Pooled Cross-Country Data. Ecological Economics, 44, 29-42.

Uddin, M. M. M. (2014). Causal Relationship between Education, Carbon Dioxide (CO2 ) Emission and Economic Growth in Bangladesh. IOSR Journal of Humanities and Social Science, 19(4), 60-67.

WMO. 2018. WMO. Press Release, Geneva, (online), (https://public.wmo.int/en/media/ press-release/greenhouse-gas-levels-atmosphere-reach-new-record diakses pada 25 november 2019).

WRI. 2012. Top 10 Emitters in 2012. (Online)(https://www.wri.org/resources/charts-graphs/ top-10-emitters-2012 diakses pada 15 november 2019).

WRI. 2014. Graph explain the world's top 10 emitters. (Online), (https://www.wri.org/ blog/2014/11/6-graphs-explain-world-s-top-10-emitters diakses pada 10 november 2019).

York, R., Rosa, E. A., \& Dietz, T. (2003). STIRPAT, IPAT and ImPACT: analytic tools for unpacking the driving forces of environmental impacts. Ecological Economics, 46(3), 351-365. 